\title{
Comparative Study Between Budgeted and Actual Total Revenue, Total Expenditure of Sri Lanka
}

\author{
V. Anojan (Corresponding Author) \\ Department of Accounting, Faculty of Management Studies and Commerce \\ University of Jaffna, Sri Lanka \\ Tel: 94-778-394-018Ｅ-mail: v.anoabt@gmail.com \\ B. Nimalathasan \\ Department of Accounting, Faculty of Management Studies and Commerce \\ University of Jaffna, Sri Lanka
}

Received: September 1, 2018 Accepted: September 18, 2018 Published: September 25, 2018

doi:10.5296/ijafr.v8i3.13585

URL: https://doi.org/10.5296/ijafr.v8i3.13585

\begin{abstract}
The main aim of this study is to find out mean difference between budgeted total revenue, expenditure and actual total revenue and expenditure of Sri Lanka from 2005 to 2017. Budget deficit is a major problem in Sri Lanka. Budget deficit of the country is increasing in every year. Every country is trying to reduce the budget deficit and it has budget as key controlling tool. If any country is unable to meet its budget for continuous and longer period of time, it will create vital economic problem for that country. According to annual report of Sri Lanka (2017), Sri Lanka had actual total revenue lower than budgeted total revenue as well as Sri Lanka had actual total expenditure lower than budgeted total expenditure. Budgeted revenue and actual revenue were as respectively LKR 1,913,650 and 1,845,017 million. Further budgeted expenditure and actual expenditure were as respectively LKR 2,962,211 and 2,603,105 million. Data of this study has been analyzed by using many statistical tools such as mean, standard deviation and independent samples t-test. The statistical results of this study reveals that there is no significant mean difference between budgeted revenue, expense and actual revenue, expense of Sri Lanka from 2005 to 2017. Sri Lanka had tax revenue, non-tax revenue and total revenue more than budget in 2007. Sri Lanka did not meet the budgeted revenue and expense during 2005 to 2017.
\end{abstract}

Keywords: Budgeted revenue, Actual revenue, Budgeted expenditure and actual expenditure, Sri Lanka 


\section{Introduction}

Total revenue and total expenditure are the major variables of government budget deficit as well in the government budget. Generally government try to prepare the budget as favorable and more accurately. Even some governments are unable to meet the budgeted revenue and expenditure. Sri Lanka also fails to meet the budgeted revenue and expenditure for example budgeted revenue and expenditure were respectively LKR 1,913,650 and 2,962,211 million in 2017, however actual revenue and expenditure were respectively 1,845,017 and 2,603,105 million in 2017. Many governments try to increase the revenue of the country and maximum try to control the expenditures of the country.

\subsection{Total Revenue (TR)}

Total revenue of the county can be seen as two major parts of income such as tax revenue and non-tax revenue. Sri Lankan tax revenue covers the following revenues such as, income tax, taxes on domestic goods \& services and taxes on international trade. As well as Sri Lankan non-tax revenue covers the following revenues such as railways, postal, stores advance accounts (explosive items), prisons industrial and agricultural advance account, rent, interest, profits, dividends, transferring surplus fund from public enterprises, departmental sales, administrative fees \& charges, fees under the motor traffic act \& other receipts, registration fees on motor vehicle transfers under the issuing motor vehicle permits on concessionary terms, fines and forfeits and other receipts. Annual Report 2017, Ministry of Finance, Sri Lanka reveals that more than $91 \%$ total revenue from tax revenue in Sri Lanka.

\subsection{Total Expenditure (TE)}

Total expenditure of the county can be seen as two major parts such as recurrent expenditure and capital \& development expenditure. Sri Lankan recurrent expenditure covers the following expenditures such as salaries, wages and other employment benefits, other goods \& services, subsidies, grants and transfers, interest payments and other recurrent expenditure. As well capital \& development expenditure covers the following expenditures such as rehabilitation and improvements of capital assets, acquisition of capital assets, capital transfers, acquisition of financial assets, human resource development and other capital expenditure. Annual Report 2017, Ministry of Finance, Sri Lanka reveals that more than $75 \%$ total expense by recurrent expense in Sri Lanka.

\subsection{Problem Statement}

Budget deficit is one of the major problem and it is continuing in Sri Lanka. According to the annual report of Sri Lanka (2017), it can be seen that total revenue, total expenditure and budget deficit were respectively as LKR 1,845,017 LKR 2,603,105 and 758,088 million in Sri Lanka. Here budget deficit of the country and total revenue of the country is $0.41: 1$. Effective budget preparation budget control should be needed to reduce and improve the budget deficit of Sri Lanka. Budget is one of the key tools to control the revenue and increase income of the country. Sri Lanka is trying to reduce the budget deficit through various ways but cannot reduce the budget deficit. It is important one budget should be achieved in every country especially in developing countries. Every country should maximum try to meet the 


\section{Ml Macrothink}

International Journal of Accounting and Financial Reporting

ISSN 2162-3082

2018, Vol. 8, No. 3

budget of the country in every year. Sri Lanka has the problem, cannot achieve the budget. The following research questions were formulated in this study.

\subsubsection{Research Question (RQ)}

According to the best of existing literature, empirical review and economy of Sri Lanka, the following research questions (RQ) were formulated for this study.

$\mathbf{R Q}_{\mathbf{1}}$ : Is there any mean difference between budgeted total revenue and actual total revenue of Sri Lanka?

$\mathbf{R Q}_{2}$ : Is there any mean difference between budgeted total expenditure and actual total expenditure of Sri Lanka?

$\mathbf{R Q}_{3}$ : Does Sri Lanka meet the budgeted total revenue and total expenditure in every year of this study?

\subsection{Significance of the Study}

This study mainly focus on identify mean difference between budgeted revenue, expense and actual revenue and expense of Sri Lanka from 2005 to 2017. Sri Lanka has vital economic problem which is budget deficit. Budget is one of the key controls tools to control and maintain expenses of the country. Further budget will guide, motivate and communicate to achieve budget revenue of the country. Every government has national budget for their country as well Sri Lanka also has budget in every year. There is vital question which is whether budget achieved or not. This study definitely gives answer for above question. Researchers believe that budget is one of the legal documents of the country at the same time it should be ensured with actual. As best of information and knowledge of the researcher this is the first attempt in Sri Lankan context research. Reduce the budget deficit and to have budget surplus is major economic vision of Sri Lanka so this study also hope to help to reveal the current position of the country.

\subsection{Research Objectives}

The main objective of this research is to find out mean difference between budgeted and actual total revenue and total expenditure of Sri Lanka from 2005 to 2017. The following objectives could be seen as specific objectives;

- To identify mean difference between budgeted revenue actual revenue of Sri Lanka from 2005 to 2017.

- To find out mean difference between budgeted expense actual expense of Sri Lanka from 2005 to 2017.

- To reveals budgeted total revenue, budgeted total expenditure, actual total revenue, and actual total expenditure of Sri Lanka in the period of this study. 


\subsection{Scope of the Research}

The researcher considered budgeted revenue, budgeted expenditure, actual revenue and actual expenditure of the Sri Lanka from 2005 to 2017. The research focused to find out the significant mean difference between budget and actual revenue and expenditure of Sri Lanka. Annual reports of Sri Lanka used from 2005 to 2017 in this study which were published by the Ministry of Finance, Sri Lanka.

\section{Literature Review}

There are number of studies related with this study however researchers of this study can ensure that there is no research on this particular topic in Sri Lanka. Ritesh and Tejaswini (2016) stated that controlling over the expenditure is the most important objective of any budget. The Budget which focuses only on revenue generation and not on expenditure controlling cannot perform up to the expectation of the society. They noted that the efficiency of controlling in expenditure can be analyzed by comparing the budgets and actuals after the actual are realized. The main aim of this study was to find out the efficiency of Haryana budget in relation to controlling the expenditures. Researchers did a comparison of budgeted and actual expenditure provided in the Haryana budget. This study covered mean, standard deviation and independent t-test statistical analysis. The statistical results confirmed that there was no significant difference between budgeted and actual expenditure whether non-plan, plan, revenue expenditure or capital expenditure.

According to Nemanja (2015) in the field of public finances, the issue of potential links between government revenue and government expenditure has intensely attracted the attention of policy makers. On the one hand, the needs for government investments are constantly increasing, especially in developing countries, while, on the other, the access to high government revenues through tax collection is presents a constant difficulty due to low income per capita in these countries. Researcher noted that the key macroeconomic imbalance in the Republic of Serbia is largely conditioned by an increasing share of fiscal deficit in gross domestic production. Researcher found that effects of the budget deficit which has been present for a long period of time culminated in 2009, when it reached $3.4 \%$ and exceeded the value prescribed by the Maastricht criteria. Namely, the continuous growth of the budget deficit is a source of instability and it seriously endangers the functioning of public finances in the Serbian economy.

Benethelin, Benjamin and Paul (2001) this study assessed expenditure efficiency on education and health in Namibia. This study covered the votes and the type of expenditure on education and health during the period 1990/91 to 2000/01. This study examined and compared to relevant performance indicators. Researchers noted two sectors combined consume marginally below half of the total national budget and these sectors are believed to have a greater multiplier effect on the economy in the long term and eventually improve the social and economic conditions of the population. The study confirmed that Namibia's educational system appears to be very financially burdensome, accounting for over $10 \%$ of gross domestic production. Further researchers stated that capital expenditure on education has been minimal and there are no prospects for the situation to change given resource 
constraints. They noted that ten years after independence, half of Namibians have access to primary health care services. Social and health indicators for Namibia have improved during this period.

Teresa, Javier and Mika (2007) mentioned that while fiscal forecasting and monitoring has its roots in the accountability of governments for the use of public funds in democracies, the stability and growth pact has significantly increased interest in budgetary forecasts in Europe, where they play a key role in the European Union multilateral budgetary surveillance. Researchers stated that increased prominence and sensitivity of budgetary forecasts, which may lead to them being influenced by strategic and political factors. They discussed the main issues and challenges in the field of fiscal forecasting from a practitioner's perspective and place them in the context of the related literature in this study. Jadranka and Marina (2009) stated that the national budget is the main instrument through which governments collect resources from the economy, in a sufficient and appropriate manner; and allocate and use those resources responsively, efficiently and effectively. They very clearly mentioned that basic goals of public expenditure management are accomplishing macro financial discipline, strategically priorities and functional application. These three objectives are complementary and interdependent. According to the past history public expenditure management approach was put into practice in the early 1980s by World Bank.

Eugenia, Ramona and Mara (2012) performed an analysis of the volatility of the budget deficit for European Union (EU) countries. The major purpose of this study was to identify the most significant determinants of budget deficit volatility in a comparative study for old EU member states and New Member States (NMS). This study aimed to test the impact of macroeconomic variables such as public expenditures, economic growth rate, and unemployment on the budget balance volatility, based on panel data. They anticipated that the implementation of this new fiscal discipline requires a more efficient public sector for both old and NMS and a reconsideration of state intervention in the economy.

Innocent and Christopher (2017) evaluated Nigeria's federal budget and its performance. They used descriptive and analytical research method, using ex-post 'facto' data analysis of secondary data extracted from various budget documents, financial and economic reports of the Federal Republic of Nigeria. This study revealed that Federal Government budget lacks credibility except in the case of fiscal solvency / discipline in the first stage while in the second stage; study revealed that the federal budget performance is considered below average. The findings ranked Nigeria's budget / fiscal performance as sub-optima but fairly satisfactory The study recommends that, Federal Government should prepare a gazette 'Budget Performance Report' that incorporates "Year-End Revised Approved Estimates with Comparison of Actual Fiscal Performance Report" within 90 days after the last day of every financial year as this will help improve the performance of budget performance in Nigeria.

Benethelin, Benjamin and Paul (2001) assessed expenditure efficiency on education and health in Namibia. The votes and the type of expenditure on education and health during the period $1990 / 91$ to $2000 / 01$ is examined and compared to relevant performance indicators. Finding of this study revealed that Namibia's educational system appears to be very financially 


\section{MInstitute Macrothink $_{\text {Int }}$}

International Journal of Accounting and Financial Reporting

ISSN 2162-3082

2018, Vol. 8, No. 3

burdensome, accounting for over 10 per cent of GDP. Capital expenditure on education has been minimal and there were no prospects for the situation to change given resource constraints.

\subsection{Hypothesis}

The following hypotheses were developed and tested in this study according to depth literature review, research questions and objectives of this study.

$\mathbf{H}_{1}$ : There is significant mean difference between budgeted revenue and actual revenue of Sri Lanka.

$\mathbf{H}_{1 \mathbf{a}}$ : There is significant mean difference between budgeted tax revenue and actual tax revenue of Sri Lanka.

$\mathbf{H}_{1 \mathbf{b}}$ : There is significant mean difference between budgeted non-tax revenue and actual non-tax revenue of Sri Lanka.

$\mathbf{H}_{2}$ : There is significant mean difference between budgeted expenditure and actual expenditure of Sri Lanka.

$\mathbf{H}_{2 \mathbf{a}}$ : There is significant mean difference between budgeted capital expenditure and actual capital expenditure of Sri Lanka.

$\mathbf{H}_{2 \mathbf{b}}$ : There is significant mean difference between budgeted current expenditure and actual current expenditure of Sri Lanka.

\section{Research Methodology}

a) Sample of the Study

This study covers whole of Sri Lanka. Researcher considered 2005 to 2017 as study period based on the convenience of data of this study.

b) Data Source

Secondary data used in this study those secondary data was collected from annual reports and budget estimates of Sri Lanka from 2005 to 2017.

c) Data Analysis

This study involves with statistical analysis of secondary data. SPSS used to analyze the data of this study which is very popular software for secondary data as well as quantitative analysis. The following analysis performed in this study such as descriptive analysis and inferential analysis. Descriptive analysis used to reveals mean value of budgeted revenue, budgeted expenditure, actual revenue and actual expenditure of Sri Lanka. Inferential analysis used to compare the mean difference between budgeted and actual revenue and expenditure of Sri Lanka. 


\section{Results and Interpretation}

\subsection{Descriptive Analysis}

Table 1. Budgeted revenue vs. actual revenue of Sri Lanka in rupees million

\begin{tabular}{|c|c|c|c|c|c|}
\hline & Group & $\mathrm{N}$ & Mean & Std. Deviation & Std. Error Mean \\
\hline \multirow[t]{2}{*}{ Tax Revenue } & Budget & 13 & 916,337 & 416,530 & 115,525 \\
\hline & Actual & 13 & 863,139 & 401,593 & 111,382 \\
\hline \multirow{2}{*}{$\begin{array}{l}\text { Non } \\
\text { Revenue }\end{array}$} & Budget & 13 & 112,539 & 49,458 & 13,717 \\
\hline & Actual & 13 & 113,879 & 55,744 & 15,461 \\
\hline \multirow{2}{*}{$\begin{array}{l}\text { Total } \\
\text { Revenue }\end{array}$} & Budget & 13 & $1,028,877$ & 462,507 & 128,276 \\
\hline & Actual & 13 & 977,010 & 450,449 & 124,932 \\
\hline
\end{tabular}

Descriptive analysis reveals that mean value of actual tax revenue is below than mean value of budgeted tax revenue of Sri Lanka during 2005 to 2017 on the other hand it can be seen that actual non-tax revenue is higher than budgeted non-tax revenue of Sri Lanka during 2005 to 2017.

Table 2. Budgeted expense vs. actual expense of Sri Lanka in rupees million

\begin{tabular}{llllll}
\hline & Group & $\mathrm{N}$ & Mean & Std. Deviation & Std. Error Mean \\
\hline $\begin{array}{l}\text { Recurrent } \\
\text { Expense }\end{array}$ & Budget & 13 & $1,146,221$ & 530,697 & 147,189 \\
\cline { 2 - 6 } & Actual & 13 & $1,099,997$ & 481,986 & 133,679 \\
\hline $\begin{array}{l}\text { Capital } \\
\text { Expenses }\end{array}$ & Budget & 13 & 533,637 & 311,421 & 86,373 \\
\cline { 2 - 6 } & Actual & 13 & 414,086 & 180,492 & 50,060 \\
\hline $\begin{array}{l}\text { Total } \\
\text { Expenses }\end{array}$ & Budget & 13 & $1,679,858$ & 836,126 & 231,900 \\
\cline { 2 - 6 } & Actual & 13 & $1,514,037$ & 657,095 & 182,245 \\
\hline
\end{tabular}

According to Table 2, it can be found that mean value of actual recurrent expense is below than mean value of budgeted recurrent expense of Sri Lanka during 2005 to 2017 as well as it can be seen that actual capital expense is below than budgeted capital expense of Sri Lanka 
during 2005 to 2017.

\subsection{Independent - Samples T Test}

Table 3. Budgeted revenue vs. actual revenue of Sri Lanka in rupees million

\section{Independent Samples Test}

\begin{tabular}{|c|c|c|c|c|c|c|c|c|}
\hline & & \multicolumn{2}{|c|}{$\begin{array}{l}\text { Levene's Test } \\
\text { for Equality of } \\
\text { Variances }\end{array}$} & \multicolumn{4}{|c|}{ t-test for Equality of Means } & \multirow[b]{2}{*}{$\begin{array}{l}\text { Std. Error } \\
\text { Difference }\end{array}$} \\
\hline & & $\mathrm{F}$ & Sig. & $\mathrm{T}$ & $\mathrm{df}$ & $\begin{array}{l}\text { Sig. } \\
\text { (2-tailed) }\end{array}$ & $\begin{array}{l}\text { Mean } \\
\text { Difference }\end{array}$ & \\
\hline $\begin{array}{l}\text { Tax } \\
\text { Revenue }\end{array}$ & $\begin{array}{l}\text { Equal } \\
\text { variances } \\
\text { assumed }\end{array}$ & .056 & .814 & .332 & 24 & .743 & 53,199 & 160,474 \\
\hline $\begin{array}{l}\text { Non Tax } \\
\text { Revenue }\end{array}$ & $\begin{array}{l}\text { Equal } \\
\text { variances } \\
\text { assumed }\end{array}$ & .050 & .826 & -.065 & 24 & .949 & $(1,340)$ & 20,669 \\
\hline $\begin{array}{l}\text { Total } \\
\text { Revenue }\end{array}$ & $\begin{array}{l}\text { Equal } \\
\text { variances } \\
\text { assumed }\end{array}$ & .047 & .830 & .290 & 24 & .775 & 51,866 & 179,061 \\
\hline
\end{tabular}

Independent - Samples $\mathrm{T}$ Test reveals that there is no significant mean difference between budgeted total revenue, tax revenue, non-tax revenue and actual total revenue, tax revenue, non-tax revenue of Sri Lanka during 2005 to 2017. There is huge mean difference between budgeted tax revenue and actual tax revenue which is 53,199 million rupees in Sri Lanka. According to above results hypothesis $\mathbf{H}_{\mathbf{1 a}}$ and $\mathbf{H}_{\mathbf{1 b}}$ are rejected.

Table 4. Budgeted expense vs. actual expense of Sri Lanka in rupees million Independent Samples Test

Levene's Test

for Equality

of Variances $\quad \mathrm{t}$-test for Equality of Means

F Sig. t $\quad$ df

Sig.

Mean

Std. Error 
(2-tailed) Difference Difference

\begin{tabular}{lllllllll}
\hline $\begin{array}{l}\text { Recurrent } \\
\text { Expense }\end{array}$ & $\begin{array}{l}\text { Equal } \\
\text { variances } \\
\text { assumed }\end{array}$ & .137 & .714 & .232 & 24 & .818 & 46,224 & 198,833 \\
\hline $\begin{array}{l}\text { Capital } \\
\text { Expenses }\end{array}$ & $\begin{array}{l}\text { Equal } \\
\text { variances } \\
\text { assumed }\end{array}$ & 2.049 & .165 & 1.198 & 24 & .243 & 119,551 & 99,831 \\
& & & & & & & & \\
\hline $\begin{array}{l}\text { Total } \\
\text { Expenses }\end{array}$ & $\begin{array}{l}\text { Equal } \\
\text { variances } \\
\text { assumed }\end{array}$ & .574 & .456 & .562 & 24 & .579 & 165,821 & 294,942 \\
& & & & & & & & \\
\hline
\end{tabular}

According to Independent - Samples T Test, it can be seen that there is no significant mean difference between budgeted total expense, recurrent expense, capital expense and actual total expense, recurrent expense, capital expense of Sri Lanka during 2005 to 2017. There is huge mean difference between budgeted capital expense and actual capital expense which is 119,551 million rupees in Sri Lanka. According to above results hypothesis $\mathbf{H}_{\mathbf{2} \mathbf{a}}$ and $\mathbf{H}_{\mathbf{2}}$ are rejected.

\subsection{Percentage Analysis}

Table 5. Budgeted revenue vs. actual revenue of Sri Lanka in percentage (\%)

\begin{tabular}{llllll}
\hline Budgeted Revenue $\%$ & \multicolumn{5}{c}{ Actual Revenue \% } \\
\hline Tax & $\begin{array}{l}\text { Non-tax } \\
\text { Revenue }\end{array}$ & $\begin{array}{l}\text { Total } \\
\text { Revenue }\end{array}$ & $\begin{array}{l}\text { Tax } \\
\text { Revenue }\end{array}$ & $\begin{array}{l}\text { Non-tax } \\
\text { Revenue }\end{array}$ & $\begin{array}{l}\text { Total } \\
\text { Revenue }\end{array}$ \\
\hline 100 & 100 & 100 & 97.52 & 106.43 & 98.45 \\
\hline 100 & 100 & 100 & 99.12 & 98.89 & 99.10 \\
\hline 100 & 100 & 100 & 106.27 & 105.35 & 106.14 \\
\hline 100 & 100 & 100 & 86.87 & 90.86 & 87.28 \\
\hline 100 & 100 & 100 & 80.28 & 97.51 & 81.95 \\
\hline 100 & 100 & 100 & 100.65 & 91.87 & 99.58 \\
\hline
\end{tabular}




\begin{tabular}{lccccc}
100 & 100 & 100 & 98.20 & 123.19 & 101.04 \\
\hline 100 & 100 & 100 & 94.28 & 106.91 & 96.00 \\
\hline 100 & 100 & 100 & 87.78 & 101.84 & 89.43 \\
\hline 100 & 100 & 100 & 84.58 & 85.47 & 84.69 \\
\hline 100 & 100 & 100 & 99.18 & 75.79 & 96.78 \\
\hline 100 & 100 & 100 & 99.30 & 121.36 & 101.86 \\
\hline 100 & 100 & 100 & 95.45 & 106.67 & 96.41 \\
\hline
\end{tabular}

According to above percentage analysis it can be seen that budgeted tax revenue of Sri Lanka did not achieve in 11 years during 2005 to 2017 on the other hand non-tax revenue has achieved more than budgeted non-tax revenue of Sri Lanka in 7 years during 2005 to 2017.

Table 6. Budgeted expense vs. actual expense of Sri Lanka in in percentage (\%)

\begin{tabular}{lccccc}
\hline Budgeted Expenses & \multicolumn{5}{c}{ Actual Expenses } \\
\hline Recurrent & Capital & Total & Recurrent & Capital & Total \\
\hline 100 & 100 & 100 & 101.39 & 120.89 & 105.51 \\
\hline 100 & 100 & 100 & 100.06 & 95.04 & 98.85 \\
\hline 100 & 100 & 100 & 95.83 & 137.93 & 106.70 \\
\hline 100 & 100 & 100 & 104.29 & 76.18 & 95.38 \\
\hline 100 & 100 & 100 & 95.47 & 63.41 & 84.07 \\
\hline 100 & 100 & 100 & 96.01 & 87.45 & 93.56 \\
\hline 100 & 100 & 100 & 99.32 & 85.02 & 94.84 \\
\hline 100 & 100 & 100 & 98.60 & 85.01 & 94.14 \\
\hline 100 & 100 & 100 & 95.62 & 83.59 & 92.09 \\
\hline
\end{tabular}




\begin{tabular}{lccccc}
100 & 100 & 100 & 95.36 & 88.69 & 93.24 \\
\hline 100 & 100 & 100 & 94.18 & 81.87 & 90.25 \\
\hline 100 & 100 & 100 & 89.86 & 50.14 & 74.95 \\
\hline 100 & 100 & 100 & 96.00 & 70.28 & 87.88
\end{tabular}

According to above table 6, it can be seen that budgeted recurrent expense of Sri Lanka did not achieve in 10 years during 2005 to 2017 as well as capital has achieved below than budgeted capital expense of Sri Lanka in 10 years during 2005 to 2017. Further it can be seen that last ten years actual capital expense is below $90 \%$ of budgeted capital expense of Sri Lanka. Sri Lanka achieved only $50.14 \%$ of capital expense in 2016.

Table 7. Composition of tax revenue and non-tax revenue in budget and actual in \%

\begin{tabular}{|c|c|c|c|c|c|}
\hline Budgeted & & & Actual & & \\
\hline & Non-tax & Total & Tax & Non-tax & Total \\
\hline Revenue & Revenue & Revenue & Revenue & Revenue & Revenue \\
\hline 89.54 & 10.45 & 100.00 & 88.70 & 11.30 & 100.00 \\
\hline 89.63 & 10.37 & 100.00 & 89.65 & 10.35 & 100.00 \\
\hline 90.07 & 9.93 & 100.00 & 90.18 & 9.85 & 100.00 \\
\hline 89.80 & 10.20 & 100.00 & 89.38 & 10.62 & 100.00 \\
\hline 90.31 & 9.69 & 100.00 & 88.46 & 11.54 & 100.00 \\
\hline 87.73 & 12.27 & 100.00 & 88.67 & 11.32 & 100.00 \\
\hline 88.67 & 11.33 & 100.00 & 86.18 & 13.82 & 100.00 \\
\hline 86.35 & 13.65 & 100.00 & 84.80 & 15.20 & 100.00 \\
\hline 88.26 & 11.74 & 100.00 & 86.63 & 13.37 & 100.00 \\
\hline 87.72 & 12.28 & 100.00 & 87.61 & 12.39 & 100.00 \\
\hline 89.73 & 10.27 & 100.00 & 91.96 & 8.04 & 100.00 \\
\hline 88.39 & 11.61 & 100.00 & 86.16 & 13.84 & 100.00 \\
\hline
\end{tabular}



91.44
8.56
100.00
90.52
9.48
100.00

According to above table it can be seen that budgeted average tax revenue percentage is $89.05 \%$ of total budgeted revenue and actual average tax revenue percentage is $88.38 \%$ in Sri Lank during 2005 to 2017. Further it can be found that, budgeted average non-tax revenue percentage is $10.95 \%$ of total actual revenue and actual average non-tax revenue percentage is $11.62 \%$ in Sri Lank during 2005 to 2017.

Table 8. Composition of recurrent and capital expense in budget and actual in \%

\begin{tabular}{|c|c|c|c|c|c|}
\hline \multicolumn{3}{|c|}{ Budgeted Expenses } & \multicolumn{3}{|c|}{ Actual Expenses } \\
\hline Recurrent & Capital & Total & Recurrent & Capital & Total \\
\hline 78.89 & 21.11 & 100.00 & 75.81 & 24.19 & 100.00 \\
\hline 75.85 & 24.15 & 100.00 & 76.78 & 23.22 & 100.00 \\
\hline 74.00 & 26.00 & 100.00 & 66.46 & 33.61 & 100.00 \\
\hline 68.28 & 31.72 & 100.00 & 74.66 & 25.34 & 100.00 \\
\hline 64.45 & 35.55 & 100.00 & 73.18 & 26.82 & 100.00 \\
\hline 71.33 & 28.67 & 100.00 & 73.20 & 26.80 & 100.00 \\
\hline 68.67 & 31.33 & 100.00 & 71.91 & 28.09 & 100.00 \\
\hline 67.18 & 32.82 & 100.00 & 70.36 & 29.64 & 100.00 \\
\hline 70.64 & 29.36 & 100.00 & 73.34 & 26.66 & 100.00 \\
\hline 68.14 & 31.86 & 100.00 & 69.70 & 30.30 & 100.00 \\
\hline 68.01 & 31.99 & 100.00 & 70.98 & 29.02 & 100.00 \\
\hline 62.45 & 37.55 & 100.00 & 74.88 & 25.12 & 100.00 \\
\hline 68.42 & 31.58 & 100.00 & 74.74 & 25.26 & 100.00 \\
\hline
\end{tabular}

According to above table it can be seen that budgeted capital expenditure percentage average is $30.28 \%$ of total budget and actual capital expenditure is $27.24 \%$ in Sri Lank during 2005 to 2017. Further it can be found that, actual recurrent expense is more than budgeted 
recurrent expense of total budget during 2008 to 2017.

\section{Conclusion \& Suggestions}

Budget is one of the key controlling tools on public expenditure management and which is also motivating and guiding tools for revenue generation of every country. Budgeted capital expenditure percentage average is $30.28 \%$ of total budget of Sri Lanka even though actual capital expenditure is $27.24 \%$. According to above findings, it can be stated that this kind of performance regarding capital expenditure will be a vital challenge for the sustainable development of Sri Lanka. Government of Sri Lanka should take necessary action to meet budgeted capital expenditure for the sustainable development of country. Government of Sri Lanka did not meet budgeted revenue and expense during 2005 to 2017. There may be two main reasons behind this problem such as ineffective budget preparation or ineffective budget execution. Researchers strongly suggest that government should consider corrective action according to the variance analysis of budget and actual. Further budgeted capital expenditure should be achieved for the sustainable development of the country rather than current expenditure. Based on the findings of this study it can be concluded that Sri Lanka is facing problem on meet budgeted tax revenue and capital expense of the country. Tax revenue is one of the major revenue for every country due to that Sri Lanka should consider to take necessary steps to increase tax revenue and it may consider to relevant changes on tax policy of the country according to the current economic situation and position of the country. Country maximum try to reduce current expenditure and try to increase capital expenditure, direct tax revenue and non-tax revenue for the bright economic future for Sri Lanka.

\section{References}

Abdu, M., \& Melesse, A. (2014). Government Expenditure Management and Control in Ethiopia. Research Journal of Finance and Accounting, 5(11).

Benethelin, Z., Benjamin, B., \& Paul, K. (2001). Public Expenditure Management in Namibia Health and Education Sectors - Preliminary Analysis. BON Working Paper No.1/02. Retrieved from

https://www.bon.com.na/CMSTemplates/Bon/Files/bon.com.na/60/60ab485b-d576-4b8e-b41 8-73245d3aff37.pdf

Benethelin, Z., Benjamin, B., \& Paul. K. (2001). Public Expenditure Management in Namibia Health and Education Sectors - Preliminary Analysis. Bank of Namibia Research Department.

Desislava, S., \& Nikolay, P. (2012). An Empirical Evidence for the Impact of Taxation on Economy Growth in the European Union. Book of Proceedings - Tourism and Management Studies International Conference Algarve, 3

Eric, E., Uzochukwu, A., \& Moses, O. (2006). Budget and Public Expenditure across Nigerian States. African Institute for Applied Economics.

Eugenia, Ramona, \& Mara. (2012). Determinants of fiscal budget volatility in old versus new 


\section{Al Macrothink}

International Journal of Accounting and Financial Reporting ISSN 2162-3082 2018, Vol. 8, No. 3

EU member states. Working Papers. School of Economics and Management, Technical University of Lisbon. Retrieved from http://pascal.iseg.utl.pt/ depeco/wp/wp312012.pdf

Innocent, N., \& Christopher, E. A. (2017). Budget Evaluation and Government Performance: A Case of the Nigerian Economy. Journal of Economics, Management and Trade, 20(1), 1-17.

Jadranka, D., \& Marina, D. (2009). The Importance of Public Expenditure Management in Modern Budget Systems. Economics and Organization, 6(3).

Ministry of Finance Sri Lanka. (2006-2018). Annual Reports of Sri Lanka, 2005-2017. Retrieved from http://www.treasury.gov.lk/web/guest/publications/annual-report

Nemanja, L. (2015). Government Expenditure and Government Revenue - The Causality on the Example of the Republic of Serbia. Management International Conference.

Ritesh, K., \& Tejaswini. (2016). A Comparative Study of Budgeted Expenditure and Actual Expenditure in Relation to Haryana Budget. Journal of Business and Management (IOSR-JBM), AETM'16, 93-98.

Teresa, L., Javier, J., \& Mika, T. (2007). Fiscal forecasting less ones from the literature and challenges. European Central Bank. Retrieved from http://www.ecb.europa.eu or from the Social Science Research Network electronic library at http://ssrn.com/abstract_id=1054881

\section{Copyright Disclaimer}

Copyright for this article is retained by the author(s), with first publication rights granted to the journal.

This is an open-access article distributed under the terms and conditions of the Creative Commons Attribution license (http://creativecommons.org/licenses/by/4.0/) 